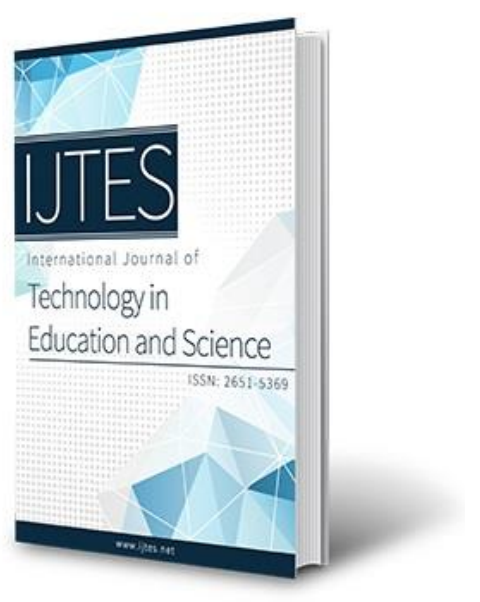

\title{
Flipgrid: Students' Perceptions of its Advantages and Disadvantages in the Language Classroom
}

\author{
Oraib Mango \\ California State University San Bernardino, USA
}

$\underline{\text { www.ijtes.net }}$

\section{To cite this article:}

Mango, O. (2021). Flipgrid: Students' perceptions of its advantages and disadvantages in the language classroom. International Journal of Technology in Education and Science (IJTES), 5(3), 277-287. https://doi.org/10.46328/ijtes.195

The International Journal of Technology in Education and Science (IJTES) is a peer-reviewed scholarly online journal. This article may be used for research, teaching, and private study purposes. Authors alone are responsible for the contents of their articles. The journal owns the copyright of the articles. The publisher shall not be liable for any loss, actions, claims, proceedings, demand, or costs or damages whatsoever or howsoever caused arising directly or indirectly in connection with or arising out of the use of the research material. All authors are requested to disclose any actual or potential conflict of interest including any financial, personal or other relationships with other people or organizations regarding the submitted work. 


\title{
Flipgrid: Students' Perceptions of its Advantages and Disadvantages in the Language Classroom
}

\author{
Oraib Mango
}

\begin{tabular}{ll}
\hline Article Info & Abstract \\
\cline { 2 - 3 } $\begin{array}{l}\text { Article History } \\
\text { Received: }\end{array}$ & The purpose of this study was to investigate students' perceptions of the effects \\
09 September 2020 & of using Flipgrid (FG) on their learning experiences and their perceptions of the \\
Accepted: & advantages and disadvantages of its use in the Arabic as a foreign/world \\
15 March 2021 & language (AWL) classroom. Thirty students participated in this study and \\
& completed a survey composed of an 18-item, 5-point Likert-type questionnaire \\
& and open-ended questions. Results indicated that even though students were \\
& skeptical about using FG in the beginning, they developed positive attitudes \\
Keywords & towards its use by the end of the semester. FG provided students with a safe, \\
Flipgrid & low-stress platform for language practice while allowing them to track their \\
Learners' perceptions & progress, which in turn helped learners gain more confidence in their listening \\
Arabic language & and speaking skills. Students enjoyed using FG and perceived it as having a \\
& positive influence on their language learning as well as on their social and \\
cognitive engagement in the classroom. The main disadvantage listed by $27 \%$ of \\
the participants was the lack of immediate feedback on their recorded Flipgrid.
\end{tabular}

\section{Introduction}

Technology has become a vital part of teaching and learning especially after the spread of COVID-19 and the educational turn towards distance learning. Consequently, educators are on the lookout for effective tools to engage students and facilitate their learning in a remote environment. This turn towards technology is vital for today’s learners and educators especially that technology has become an integral part of our lives.

In the US, 95\% of teens own a smartphone or have access to one (Anderson \& Jiang, 2018). Teens in the US spend many hours, outside of schoolwork, in front of media screens each day. Their top four favorite media activities are listening to music, watching videos, playing video games and using social media (Common Sense Media, 2019). The most popular platforms for adults between the ages of 18-24 are YouTube, Facebook, Instagram and Snapchat. All these platforms have the common feature of video viewing and sharing. Using technology that offers features valued by youth such as video viewing and sharing could prove to be very effective in education. It could build on and hone the technical and social skills that learners use every day.

Flipgrid is an educational tool that provides features similar to the popular ones provided by social media. Educators across disciplines have been using it in increasing numbers; one in three teachers in the US uses it to 
enhance student learning (Vander Ark, 2019). Its online video platform allows students to share video messages with their classmates, the instructor, and possibly other learners around the world.

\section{Review of the Literature}

\section{Flipgrid}

While there are multiple resources that guide instructors toward the implementation of Flipgrid (FG) in the classroom, there is not much empirical evidence of the effectiveness of its use in education. The few research studies that investigated the use of FG in education indicated that learners found it to be a user-friendly tool that helped learners connect with each other, and enhanced student engagement in the classroom. For example, Holbeck \& Hartman (2018) found FG to be an effective and relevant educational tool. They reported that it helped increase student engagement and communication in a secondary art classroom.

Similarly, McLain (2018) found it to be an effective learning tool for students in Business English Writing classes. Students in his study reported that FG was easy to use and that it allowed them to engage in more language practice from home. McLain also reported an increase in students' perceived confidence in their English-speaking skills. Lowenthal \& Moore (2020) investigated graduate students' perceptions of the use of FG in online courses. Students in their study found FG to be a valuable tool for promoting social presence through asynchronous video discussions.

In the field of world language teaching and learning, Garcia (2020) found that high school students of Spanish enjoyed using FG to discuss topics that were meaningful to them. FG provided them with a discussion forum that allowed them "to share their stories" in Spanish (p. 45). Similarly, Tuyet and Kang (2020) conducted a study on high school students' use of FG but focused on its effects on student anxiety. They found that FG had a positive effect on reducing EFL students' anxiety while speaking English in the classroom.

\section{Students' Perceptions}

Many factors can have an impact on student learning and success. One of these factors is student perceptions. When students are highly satisfied with their learning, they are more likely to engage in educational activities (Fredricks, Blumenfeld, \& Paris, 2004; Hu \& Kuh, 2002; Kuh et al., 2006; Prince, 2004) and as a result, succeed in their studies.

Students' perceptions of their learning experiences include their beliefs in their self-efficacy. Learners tend to develop a positive sense of self-efficacy when they see themselves succeeding after exerting effort into their learning, and when they are appraised by others as likely to succeed (Bandura, 1995, as referenced in Graham, 2006). This is especially relevant in language learning. Student effort and strategies are important for success in the language classroom (Graham, 2006). When students see their language skills improving, they develop a positive sense of their self-efficacy, which in turn motivates them to put effort into their learning. The more improvement they see, the more invested in their learning they become. Research has shown that self-efficacy is 
related to educational outcomes. It relates to academic persistence and performance (Gallagher, Marques, \& Lopez, 2017). In addition, a positive sense of self-efficacy can be important in "maintaining motivation in the face of difficulties and failure" (Graham, 2006, p. 297).

\section{Speaking and Listening}

Meaningful communication is a main goal of language teaching and learning. Many factors can influence success in second language acquisition. These include exposing learners to comprehensible input, providing a safe and low-stress learning environment, as well as increasing student motivation and self-confidence (Krashen, 1982).

WL educators focus on developing students' communication skills by focusing on productive (speaking and writing), and receptive skills (reading and listening) while also developing intercultural proficiency. Of all these skills, scholars have found that listening comprehension has received less attention in LL2 research (Tschirner, 2016; Vandergrift, 2007). Consequently, scholars have emphasized the importance of enhancing listening comprehension skills especially that learners' proficiency levels in listening tend to lag behind their productive skills (Tschirner, 2016). In addition, language learners tend to worry most about their speaking and listening comprehension (Horwitz \& Horwitz, 1986).

\section{Research Questions}

The purpose of this study was to investigate students' attitudes and perceptions of the use of Flipgrid in the Arabic as a World language classroom (AWL). The study aimed at answering the following questions:

1. What are students' attitudes towards the use of Flipgrid in the AWL classroom? How did these attitudes change, if at all, throughout the duration of the course?

2. What are students' perceptions of the effects of the use of Flipgrid on their speaking and listening skills?

3. What are the main advantages and disadvantages of using Flipgrid for LL from the students' perspectives?

\section{Method}

The participants in this study were 30 students enrolled in AWL courses at a university in the Southwest of the US in the 2017/2018 academic year. The participants used FG outside the classroom on a weekly basis to post video responses to assignments that complemented their classroom learning. The FG assignments were posted online on Friday of every week and were due on Monday of the following week. This arrangement aimed at allowing students to practice their speaking and listening over the weekend and on days where they had no formal classroom instruction. Students used FG to record their responses to certain visual and audio prompts posted by the instructor for that particular FG. For some Flipgrids, especially ones where students were likely to need modeling, the instructor posted her own videos to model the activity for the students. 
Students' perceptions of the effects of the use of FG on their learning were investigated using a 5-point Likerttype questionnaire. The items in the questionnaire aimed at exploring students' perceptions of the effects of the use of FG on their speaking and listening skills in Arabic. The participants completed the questionnaire online during the last week of classes and were asked to state their level of agreement with each item ranging from 1= Strongly Disagree (SD) to 5= Strongly Agree (SA). In addition, the questionnaire also included open-ended questions that aimed at shedding more light on students' perceptions of the advantages and disadvantages of using FG in the classroom.

\section{Results}

\section{Students' Attitudes}

To answer the first research question investigating students' attitudes toward the use of FG in the Arabic language classroom, the data were analyzed and summarized under the following categories: affect, social engagement, and cognitive engagement.

Affect. Students had a positive attitude towards the use of FG. Data indicated that Students enjoyed using FG, and found it easy to use as well as helpful in their overall learning. The majority of the students (67\%) agreed or strongly agreed that FG was easy to use $(M=4.4), 60 \%$ of students indicated that they enjoyed using it $(\mathrm{M}=3.7)$ and $57 \%$ of students indicated that it facilitated their learning $(\mathrm{M}=3.7)$. The overall mean of students' affective perceptions of using FG was 3.8. Table 1 below shows the mean of the results of students' responses on five questions investigating students' overall perceptions of FG on a scale of 1-5.

Table 1. Students' Perceptions of the Use of FG

\begin{tabular}{lc}
\hline Item & Mean \\
\hline Flipgrid is easy to use & 4.4 \\
Flipgrid helped my learning in this class & 3.6 \\
I like Using Flipgrid in Language Learning & 3.6 \\
Flipgrid served as a learning aid in this course & 3.8 \\
I enjoyed listening to / watching my classmates' Flipgrid & 3.7 \\
\hline
\end{tabular}

Social Engagement. Students had a positive perception of the influence of FG on their social engagement in the course. In terms of participation, $67 \%$ of the participants agreed or strongly agreed that FG helped them participate in speaking activities $(\mathrm{M}=4)$. Most of the participants $(53 \%)$ also agreed or strongly agreed that FG helped develop their confidence in their speaking skills $(M=3.3)$. These results are in line with McLain's (2018) findings which indicated that $42.9 \%$ of English language learners in a business writing class felt more confident speaking English because of using FG. In addition, half of the participants agreed or strongly agreed that FG helped them better relate to their classmates $(M=3.6)$ (see Table 2). 
Table 2. Students' Perception of Effects of FG on Social Engagement

\begin{tabular}{lc}
\hline Item & Mean \\
\hline Flipgrid helped me relate better with students in this class & 3.6 \\
Flipgrid helped me develop confidence in my public speaking skills & 3.3 \\
Flipgrid helped me participate in speaking activities & 4 \\
\hline
\end{tabular}

Cognitive Engagement. The data suggested that FG facilitated students' cognitive engagement in terms of putting time and effort into their learning (see Table 3); 63\% agreed or strongly agreed that they practiced repeatedly before recording. As a result, students put more thought into their speaking when using FG $(M=3.6)$.

Table 3. Students' perception of Effects of FG on Cognitive Engagement

\begin{tabular}{lc}
\hline Item & Mean \\
\hline I practiced my speaking assignment over and over before recording on Flipgrid & 3.9 \\
I practiced my Flipgrid before recording it & 4 \\
My recordings on Flipgrid are more well thought out than if I were speaking & 3.6 \\
face to face & \\
\hline
\end{tabular}

\section{Change in Attitude}

In terms of the second part of the first research question, most of the students expressed skepticism over the use of FG at the start of the course; some did not want to use it while others were unsure of its usefulness. Out of 27 students who answered this part, 18 indicated that their attitudes became positive when they realized its positive impact on their learning. Below are samples of students' responses:

"I hated it because of the camera but now I am way better."

"I was hesitant with it at the beginning, but now I like it a lot. My attitude changed with it as it has helped me with speaking."

"Honestly at first I was not with it, but when I saw the benefits of my overall practice it was good."

Eight students expressed that they had positive attitude toward FG from the onset

"I have always liked Flipgrid since the beginning."

"I enjoyed it from the beginning."

"At the beginning I really liked Flipgrid and I still do. My attitude towards it didn't change much. It is a great tool to improve all types of learning."

Only one student indicated that they stopped liking FG as the course progressed (see Table 4).

Table 4. Students' Change of Attitude

\begin{tabular}{lc}
\hline Change of attitude & \# students \\
\hline From skeptical to positive & 18 \\
Constantly positive & 8 \\
From positive to negative & 1 \\
\hline
\end{tabular}




\section{Students' Perceptions of the effects of using Flipgrid on their Speaking and Listening Skills}

In terms of the second research question regarding students' perceptions of the effects of FG on their listening and speaking skills, 53\% of the participants agreed or strongly agreed that FG helped them develop their listening and speaking. The overall mean of student perceptions of the effects of using FG on their speaking and listening was 3.7 (see Table 5), which indicates a positive perception. The highest mean in this category was the one measuring students' perceptions of the positive effects of their instructor's recordings on their learning $(\mathrm{M}=4.1)$; most of the students $(73 \%)$ indicated that their instructor's FG recordings helped their learning. In comparison, $50 \%$ of learners indicated that they learnt from their classmates' FG recordings, and $46 \%$ agreed or strongly agreed that listening to their own recordings helped them learn.

Table 5. Students' Perceptions of Effects of FG on Speaking and Listening

\begin{tabular}{lc}
\hline Item & Mean \\
\hline Flipgrid helped develop my Speaking skills & 3.6 \\
Recording my voice helped me develop my speaking skills & 3.8 \\
Flipgrid helped develop my Arabic pronunciation & 3.7 \\
Listening to other students' Flipgrids helped in my language learning & 3.5 \\
Listening to my own recording helped in my language learning & 3.5 \\
My instructor's Flipgrid recording helped my learning & 4.1 \\
Flipgrid helped develop my Listening skills & 3.7 \\
\hline
\end{tabular}

\section{Advantages and Disadvantages of using Flipgrid}

The questionnaire included an open-ended part that aimed at investigating students' perceptions of the advantages and disadvantages of using FG.

Advantages. Students' responses were analyzed and grouped under three main categories:

1- Speaking and listening practice in a low-stress environment

2- Tracking language progress

3- Confidence and Self-regulation

The majority of students' responses $(75 \%)$ belonged to the first two categories. The three categories agree with the quantitative part of the questionnaire since $53 \%$ of the participants agreed or strongly agreed that FG helped them develop their speaking and listening skills as well as their confidence in their public speaking.

\section{1-Speaking and listening practice in a stress-free environment}

Students indicated that FG allowed them to practice and develop their speaking and listening skills in a relatively risk-free environment. Students appreciated that they could a) practice as much as needed with minimal risk, b) redo their recordings before posting them, c) listen to the instructor's and other students' 
recordings whenever needed. Here are some of the students' responses:

"Being able to practice speaking"

"The ability to speak the language confidently without being judged"

"Being able to redo recordings multiple times to get the right one"

"It allows me to see other students work so I can get help."

"Being able to hear your instructor's Flipgrid before recording your own and listening to other students' pronunciation of words"

"The best thing about using Flipgrid is that you can rerecord your Flipgrid if you make a mistake."

"Rehearsing useful words and phrases over and over so that they stick better"

"I am able to practice speaking and pronunciation when I use Flipgrid."

\section{2-Tracking language progress}

Students could track their learning and were aware of the progress they were making. Here are some of the students' responses:

"The best thing about FG is that I get to learn by listening to my voice."

"The best thing about FG was just being able to record ourselves and listening to see if what we said made sense."

"Flipgrid challenges me to speak and enunciate, it helped me with speaking and pronunciation. It enhances your speaking abilities."

"The best is being able to express a topic in your own words do you get to see your weakness in the language and what to improve on."

"When I listen to my recording, I am able to hear words that are not clear or I do not pronounce correctly. I am able to hear how I sound when speaking Arabic."

"Helping a lot to improve yourself."

\section{3-Building confidence in one's abilities}

About $25 \%$ of the responses focused on gaining confidence in their speaking and listening skills. Here are some of the students' responses:

"I think Flipgrids gave me more confidence in that if I speak I am not thinking of every word but rather thinking of the simplest way of delivering my message."

"The ability to speak the language confidently without being judged"

Disadvantages. Twenty-two students responded to this part of the questionnaire. About $36 \%$ of these students indicated that they found no disadvantages to using FG. However, 27\% of the responses pointed to lack of immediate feedback as a disadvantage, "the potential of being incorrect and not being able to be corrected right away", "I don't know if I did it right or wrong", "maybe if it had like a helper to help pronounce the words with us." 
A few students (14\%) mentioned their discomfort with speaking publicly in front of others, "it stresses me out that I'm publicly speaking unconfidently so it's just scary." Around 9\% of the respondents found the FG assignments tedious while the rest of the responses (14\%) pointed toward logistics such as forgetting to do the Flipgrids and technical problems.

\section{Discussion}

There are multiple factors that can affect students' academic success. They include learners' positive attitudes towards learning (Fredricks, Blumenfeld, \& Paris, 2004; Hu \& Kuh, 2002; Prince, 2004), the effort and time they put into their learning, as well as learners' perceptions of their self-efficacy (Bendura, 1993; Gallagher, Marques, \& Lopez, 2017). The current study indicated that participants had a positive attitude towards using FG in the classroom and viewed it as a safe platform for speaking practice. In addition, the use of FG allowed learners to track their progress and develop a sense of accomplishment and self-efficacy.

Learners perceived FG as a helpful tool in developing their language skills. It allowed learners more autonomy in their learning; they could practice as much as needed before submitting their posts; they had access to language input through peer and instructor recordings; they could listen to their own recordings before posting them; and they had the flexibility of choosing when, where and what to record in response to the instructor's prompts. In addition, learners expressed more confidence in their speaking and listening abilities because they could listen to their own posts and track their progress. FG facilitated students' participation in speaking activities thus enhancing their learning; "students who actively participate in the learning process learn more than those who do not" (Weaver \& Qi, 2005, p. 570). Students reported that as they tracked their language progress, they gained more confidence, which in turn, motivated them to put more effort into their learning.

Even though students enjoyed using FG, the data showed that most of them were skeptical about using it at the beginning. It was only after they became aware of their progress and could track it on FG that they developed a positive attitude towards it. Students' positive perceptions of their self-efficacy affect their success and motivation to learn (Bendura, 1993). Students in this study could track their progress on Flipgrid. As a result, they developed a more positive attitude toward FG and toward their success as language learners.

The data also revealed tension in students' responses. While students appreciated the learning autonomy that FG afforded them (safe platform for language practice, reflection and self-assessment), some also gravitated towards wanting immediate instructor feedback. Students listed absence of immediate feedback as the main disadvantage of using FG. This tendency to navigate toward the instructor as the main source of learning is congruent with the responses of $75 \%$ of the students who expressed that their instructor's recording was the most helpful component of their FG learning.

This tension between learner autonomy and dependence on the instructor points towards a need for balancing the two in the language classroom. That balance would allow learners to gain enough confidence to trust their abilities to assess their progress without needing constant and immediate feedback for every task. They could 
still refer to the instructor's guidance without "needing" her feedback every step of the way.

While this study demonstrated evidence that FG could have positive academic and social effects on student learning in the language classroom, not all students welcomed its use. While for many, it offered a safe environment for speaking and listening practice, for a few others, public speaking still made them nervous even on FG. The role of language educators is to strive to create a welcoming space for all learners whether or not they are nervous about public speaking. Therefore, it is important to follow students' lead in understanding what that means for each of them while still seeking opportunities that encourage learners to reach their full potential and take risks. Some learners may find FG valuable in providing a safe environment; others may not share that perception.

To ensure student success, it is important to include learners' reflections and feedback in curriculum design, and to offer students a choice of the modalities that they may use to display their learning and understanding.

In terms of the two main disadvantages that students listed in their responses, it is worth noting that FG has included features that allow students to record their videos using different creative "effects" which may alleviate students' anxiety about public speaking. Moreover, FG allows different ways to send feedback to students including private and public videos and texts.

\section{Conclusion}

This study investigated students' perceptions of the effects of using Flipgrid on their learning experiences, and their perceptions of the advantages and disadvantages of its use in the Arabic as a world language classroom. In the WL classroom, listening and speaking practice is essential for developing students' communicative competence. Research has shown that language learners worry mostly about their speaking and listening comprehension (Horwitz \& Horwitz, 1986), and that learners' proficiency levels in listening tend to lag behind their productive skills (Tschirner, 2016). This study indicated that FG allowed students the ability to practice both of these skills in a safe, low-stress learning platform. Because FG allowed students to track their progress, they reported feeling more confidence in their language skills. They enjoyed using FG and perceived it as having a positive influence on their learning as well as on their social and cognitive engagement in the classroom.

In this study, students were skeptical about using Flipgrid in the beginning, but developed positive attitudes towards its use by the end of the semester. This finding demonstrates the importance of flexibility and student open-mindedness towards new ways and modalities of learning. Furthermore, the findings imply a tension between the ways that students positioned themselves as taking control of their learning vs depending on their instructor. Ultimately, they tended to gravitate toward teacher input and feedback as the optimal source of knowledge. This finding engenders the following questions for future research: How can educators promote learner autonomy in classrooms when students tend to gravitate toward the instructor as main source of learning? How can educators boost learners' confidence in themselves as peer teachers and learners? 
The data in this study indicated that the effective use of FG in the language classroom can help increase student engagement and promote their success. Further studies with larger number of students and within different disciplines may shed more light on the effects of FG use in education.

\section{References}

Anderson, M. \& Jiang, J. (2018). Teens, Social Media \& Technology. Pew Research Center. Retrieved from http://www.pewinternet.org/2018/05/31/teens-social-media-technology-2018/

Bandura, A. (1993). Perceived self-efficacy in cognitive development and functioning. Educational Psychologist, 28(2), 117-148. Retrieved from https://doi.org/10.1207/s15326985ep2802_3

Common Sense Media. (2019, October 28). The Common Sense Census. Media Use by Tweens and Teens. Retrieved from https://www.commonsensemedia.org/research/the-common-sense-census-media-use-bytweens-and-teens-2019

Fredricks, J. A., Blumenfeld, P. C., \& Paris, A. H. (2004). School engagement: Potential of the concept, state of the Evidence. Review of Educational Research, 74(1), 59-109.

García, A. (2020). Provoking Emotions of Sympathy and Anger to Enhance Speaking Output in the Target Language [Unpublished master's thesis]. Southern Oregon University.

Gallagher, M., Marques, S., \& Lopez, S.J. (2017). Hope and the academic trajectory of college students. Journal of Happiness Studies, 18, 341-352. Retrieved from https://doi.org/10.1007/s10902-016-9727-z

Graham, S. (2006). A study of students' metacognitive beliefs about foreign language study and their impact on learning. Foreign Language Annals, 39(2), 296-309. Retrieved from https://doi.org/10.1111/j.19449720.2006.tb02267.x

Holbeck, R., \& Hartman, J. (2018). Efficient strategies for maximizing Online Student satisfaction: Applying technologies to increase cognitive presence, social Presence, and teaching Presence. Journal of Educators Online, 15(3) 91-95.

Horwitz, E. K., Horwitz, B. \& Cope, J. (1986). Foreign language classroom anxiety. Modern Language Journal, 70(2): 125-132.

Hu, S., and Kuh, G. D. (2002). Being (dis) engaged in educationally purposeful activities: The influences of student and institutional characteristics. Research in Higher Education, 43(5): 555-575.

Krashen, S. D. (1982). Principles and practice in second language acquisition. Oxford: Pergamon.

Kuh, G. D., Linzie, J., Buckley, J. A., Bridges, B. K., \& Hayek, J. C. (2006). What Matters to Student Success: A Review of the Literature (Commissioned Report for the National Symposium on Postsecondary Student Success: Spearheading a Dialog on Student Success) (pp. i-151). National Postsecondary Education Cooperative.

Lowenthal, P. R., \& Moore, R. (2020). Exploring student perceptions of Flipgrid in online courses. Online Learning Journal, 24(4), 28-41. https://doi.org/10.24059/olj.v24i4.2335

McLain, T. (2018). Integration of the video response app FlipGrid in the business writing classroom. International Journal of Educational Technology and Learning, 4(2): 68-75.

Prince, M. (2004). Does active learning work? A review of the research. Journal of Engineering Education, 93(3), 223-231. 
Perrin, A. \& Anderson, M. (2019). Share of U.S. adults using social media, including Facebook, is mostly unchanged since 2018. Retrieved from https://www.pewresearch.org/fact-tank/2019/04/10/share-of-u-sadults-using-social-media-including-facebook-is-mostly-unchanged-since-2018/

Tuyet, T. \& Khang, N. (2020). The influences of the Flipgrid app on Vietnamese EFL high school learners' speaking anxiety. European Journal of Foreign Language Teaching, 5(1): 128-149.

Tschirner, E. (2016). Listening and Reading Proficiency Levels of College Students. Foreign Language Annals, 49(2), 201-223. Retrieved from https://doi.org/10.1111/flan.12198

Vandergrift, L. (2007). Recent development in second and foreign language listening comprehension research. Language Teaching, 40(3), 191-210.

Vander Ark, T. (2019, July 1). Teachers Flip over Flipgrid. Retrieved from https://www.forbes.com/sites/tomvanderark/2019/07/01/teachers-flip-over-flipgrid/?sh=4a1d5b82641a

Weaver, R. \& Qi, J. (2005). Classroom Organization and Participation: College Students' Perceptions. The Journal of Higher Education, 76 (5), 570-601. Forbes.

\section{Author Information}

\section{Oraib Mango}

D https://orcid.org/0000-0001-7733-375X

California State University San Bernardino

5500 University Parkway

San Bernardino, CA 92407

USA

Contact e-mail: omango@csusb.edu 